\title{
Fertilization Effects on Early Growth, Aboveground Biomass, Carbon Storage, and Leaf Characteristics of Eucalyptus pellita F. Muell. in South Sumatera
}

\author{
Pandu Yudha Adi Putra Wirabuana ${ }^{1}$, Ronggo Sadono ${ }^{2 *}$, Sergian Juniarso ${ }^{3}$
}

\author{
${ }^{1}$ Department of Research and Development, TROFSIT Institute Jln. Kaliurang KM16, Yogyakarta, Indonesia 55281 \\ ${ }^{2}$ Department of Forest Management, Faculty of Forestry, Universitas Gadjah Mada, Jln. Agro No.1, Bulaksumur, \\ Yogyakarta, Indonesia 55281 \\ ${ }^{3}$ Department of Research and Development, PT Musi Hutan Persada, Subanjeriji \\ Jln. PT TEL-Rambang Dangku, Muara Enim, Indonesia 31172
}

Received September 20, 2019/Accepted November 12, 2019

\begin{abstract}
Fertilization is one of the nutrient management efforts that play an important role in improving the productivity of plantation forests. It was conducted to provide adequate nutrients for the plant at the initial growth period when the availability of soil nutrients is very limited. The optimum dose offertilization for each plant is different depending on its requirement, climate, and soil properties. This study investigated the influence of fertilization on early growth, aboveground biomass, carbon storage, and leaf characteristics in Eucalyptus pellita in the sixth months after field establishment. An experiment comprising four treatments of fertilization, i.e., 0, 75, 133, and $167 \mathrm{~kg} \mathrm{ha}^{-1}$ of triple superphosphate $46 \% \mathrm{P}_{2} \mathrm{O}_{5}$ was set up using randomized complete block design with five replications. Four indicators were selected to evaluate the early growth of E. pellita, namely survival rate, height, the collar of diameter, and crown projection area. Aboveground biomass and carbon storage of E. pellita were estimated in each component, covering stem, bark, branches, and leaves. The leaf characteristics of E. pellita were described by individual leaf area, individual leaf dry weight, specific leaf area, and leaf area index. Results showed that the different treatment of fertilization did not have a meaningful effect on survival rate, individual leaf area, and specific leaf area. The treatments presented a substantial effect on other indicators such as height, diameter, crown projection area, aboveground biomass, carbon storage, individual leaf dry weight, and leaf area index. Despite the fact that the highest mean of height and collar of diameter were observed in the dose of $167 \mathrm{~kg} \mathrm{ha}^{-1}$, the greatest average of aboveground biomass and carbon storage were noted in the rate of $133 \mathrm{~kg} \mathrm{ha}^{-1}$. Nevertheless, this study did not find a highly different performance of E. pellita between both treatments statistically.
\end{abstract}

Keywords: nutrient management, plantation forest, crown projection area, leaf area index

*Corresponding author, email: rsadono@ugm.ac.id, phone: +62-274-548815,fax: +62 -274-548815

\section{Introduction}

Plantation forest has been widely established around the world and provides a meaningful contribution to the future viability of forestry industry (Payn et al., 2015). It also plays an important role in rural development and climate change mitigation (Nambiar, 2015). A study documents the establishment of a plantation forest is very helpful in accelerating the reforestation program and stabilize timber production in many countries (Sasaki et al., 2016). More than $35 \%$ of global wood demand was supplied by plantation forests (Mcewan et al., 2019). Therefore, sustainable plantation forest management becomes an interesting issue in the forestry sector.
Eucalypts plantation is one of the most valuable plantation forests in tropical countries. Approximately 20 million ha of eucalypts plantation have been managed intensively and deliver a positive influence on improving gross domestic products (Booth, 2013). To date, the primary objective of eucalypts plantation management is still dominated to supply raw materials for pulp and paper industry (Pirralho et al., 2014), even though several studies have reported that the quality of eucalypts wood can be used in another industry such as construction, veneer, plywood, and renewable energy (Lumbres et al., 2015; Hii et al., 2017; Simetti et al., 2018). In Southeast Asia, around six eucalypts species have been commercially developed in plantation 
forests, including E. dunni, E. grandis, E. globulus, E. urophylla, E. camaldulensis, and E. pellita (Nambiar \& Harwood, 2014). Among those species, E. pellita is the most important species for plantation forests in Indonesia. It is a native species from Papua New Guinea, Irian Jaya, and North Queensland (Harwood et al., 1997). This plant is classified into fast-growing species and has highly tolerant of a wide range of environmental gradient.

Development of $E$. pellita in Indonesia obtains a high attention after the productivity of Acacia mangium declined rapidly due to the impact of pest and disease (Hardie et al., 2018). This species is selected because it is more resistance against pest and disease and demonstrates better survival than other alternative plants in species trials. Even though it has been managed almost third rotation, the productivity of E. pellita is relatively lower than A. mangium from previous rotation in a similar site. In addition, the mean annual increment of $E$. pellita in Indonesia is about $16-17 \mathrm{~m}^{3} \mathrm{ha}^{-1}$, while $A$. mangium ranges $22-33 \mathrm{~m}^{3} \mathrm{ha}^{-1}$ before infected by pest and disease that decrease its productivity to $16-18 \mathrm{~m}^{3} \mathrm{ha}^{-1}$ (Nambiar \& Harwood, 2014). It indicates the growth rate of E. pellita is substantially inferior to A. mangium. A technical note informs that at the sixth months after establishment, the average height of E. pellita is about $1.9 \mathrm{~m}$ while $A$. mangium reaches closely $2.3 \mathrm{~m}$ (Inail et al., 2015). Consequently, it is very important to explore the best strategy for increasing the growth of E. pellita.

In the majority of eucalypts plantation, nutrient management generally has a significant effect on determining plant growth and development. Nutrient deficiency can reduce the growth rate and result in low performance, but the excessive amount of nutrients can also contaminate the plant and impact on its mortality (Dell et al., 2008). To provide sufficient nutrients for the plant, fertilization has an essential position in sustainable eucalypts plantation management. Besides improving soil fertility, fertilization also has a direct influence on plant productivity. For example, higher productivity of eucalypts plantation in Brazil largely depends on the additional phosphate and potassium fertilizer due to the dominant of sandy soil (Silva et al., 2013). On another side, the performance of eucalypts plantation in Spain is highly determined by the application of nitrogen and phosphate fertilizer (Viera et al., 2016). A similar condition is also noted in Vietnam, where fertilization using phosphate has a meaningful impact on the productivity gain of eucalypts(van Bich et al., 2019).

Many studies reported the majority of eucalypts species is very required phosphorus as a macronutrient in the initial growth period (Tng et al., 2014; Crous et al., 2015; Melo et al., 2016; Amezquita et al. 2018; Bassaco et al., 2018). Although the total phosphorus in soil is naturally high enough, the availability of phosphorus for the plant is very low (Shen et al., 2011). Therefore, fertilization is very needed to supply phosphorus nutrient for eucalypts. However, the most challenge of fertilization in eucalypts plantation is how to determine the optimum dose for each tree. Moreover, the response of eucalypts to fertilization can vary depending on soil properties, climate, and tree competition (Bassaco et al., 2018). An optimum dose of fertilization can be evaluated from the highest productivity of plant using several growth indicators such as height, diameter, volume, biomass accumulation, and leaf area index (Silva et al., 2016). This study investigated the effect of fertilization on early growth, biomass distribution, carbon storage, and leaf characteristics in E. pellita plantation.

\section{Methods}

Study area This study was conducted in a concession of eucalypts plantation, managed by PT Musi Hutan Persada (MHP) in South Sumatera. This area had geographic position in $\mathrm{S} 3^{\circ} 00^{\prime}-4^{\circ} 00^{\prime}$ and $\mathrm{E} 103^{\circ} 00^{\prime}-104^{\circ} 30^{\prime}$ (Figure 1). MHP had total concession area approximately 260,000 ha with an effective area for eucalypts plantation around 190,000 ha (Fujita et al., 2014). It was categorized to three forest management units, namely Subanjeriji, Lematang, and Benakat. Site quality in MHP was classified to five groups depending on the soil impending layer: A $(>150 \mathrm{~cm}), \mathrm{B}$

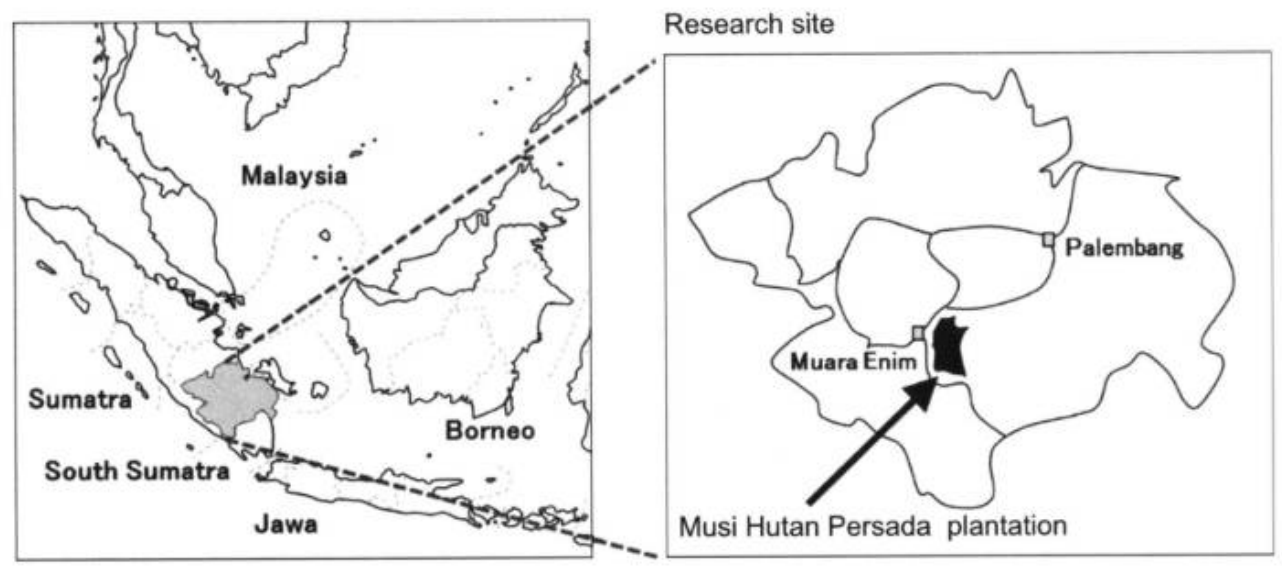

Figure 1 Study site of E. pellita plantation located in South Sumatera (Mori et al., 2018). 
(101-150 cm), C (51-100 cm), D $(26-50 \mathrm{~cm})$, and E (0-25 $\mathrm{cm})$. The majority of compartments in MHP were dominated by group $\mathrm{C}$ ranging $70 \%$ of total effective area. Topography was gradient with slope level varying 0-25\%. Altitude ranged from 60 to $200 \mathrm{~m}$ above sea level. Soil types were dominantly ultisols with high clay content. This area was classified as having humid condition with air humdity varied from 76.5 to $84.2 \%$. The average daily temperature was $29^{\circ} \mathrm{C}$ with average minimum of $23{ }^{\circ} \mathrm{C}$ and maximum of $35^{\circ} \mathrm{C}$. Annual rainfall ranged from 1,880 to $3,894 \mathrm{~mm}_{\text {year }}{ }^{-1}$ during the past 10 years from 2009 to 2018. Most of rainfall occurred between October and May with the highest rainfall was recorded in every December. Dry periods were relatively longer for 4 months between June to September.

Experimental design A randomized complete block design with five blocks ( 4 blocks for continuous measurement and 1 block for destructive sampling in certain period, i.e. 6,18 , and 36 months) was set up in this study. This design was selected due to the high environmental gradient in study area, particularly from soil condition. There were four treatments of fertilization, i.e. $0,75,133$, and $167 \mathrm{~kg} \mathrm{ha}^{-1}$ of triple superphosphate (TSP $46 \%, \mathrm{P}_{2} \mathrm{O}_{5}$ ). It was applied inside of hole when planting with the dose of fertilization for each seedling ranging 45, 75, and $100 \mathrm{~g}$. The symbol of each treatment sequentially was Control, P1, P2, and P3. Every treatment was established in a square plot (0.03 ha) consisting of 25 measured trees and 24 border trees. The existence of border trees aimed to clarify the boundaries between treatments in every replication. To facilitate the measurement process, a nameplate was installed in each treatment plot using a specific code. Each measured tree was also marked by a number identity (Figure 2).

This experiment was established in April 2018. Site preparation was conducted to ensure the distribution of biomass residue spreading evenly. It was also directed to identify the environmental gradient such as slope variation, waterlog, wind disturbances, as well as soil properties. It aimed to manage a homogenous condition in each block for minimizing the disturbance to experimental plot (Gonçalves et al., 2010). Soil sampling was undertaken at five different points in three depth layers, namely $0-10 \mathrm{~cm}, 11-0 \mathrm{~cm}$, and 21-30 cm (Li et al., 2018) (Figure 3). Then, they was composited and brought to laboratory for quality test, covering soil texture, soil acidity, soil organic carbon, and cation exchange capacity (Table 1). Soil texture was examined using hydrometer, while soil acidity was measured by $\mathrm{pH}$ meter. Walkey and Black method was used to assess soil organic carbon. In another side, cation exchange capacity was estimated using ammonium acetate method. Those processes were done referring to the guide for methods of soil, plant, and water analysis by(Estefan et al., 2013)

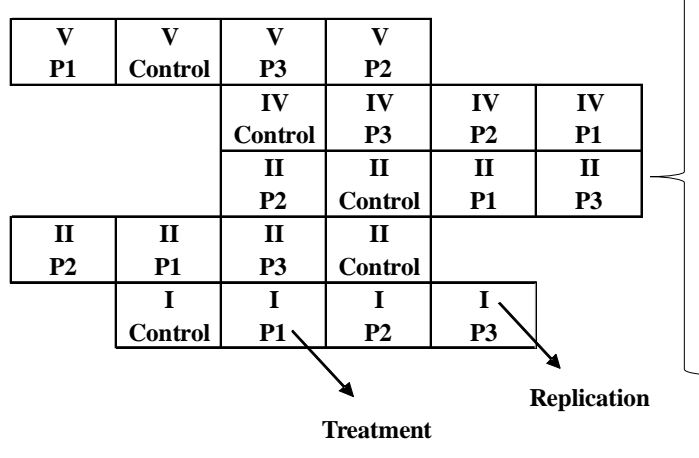

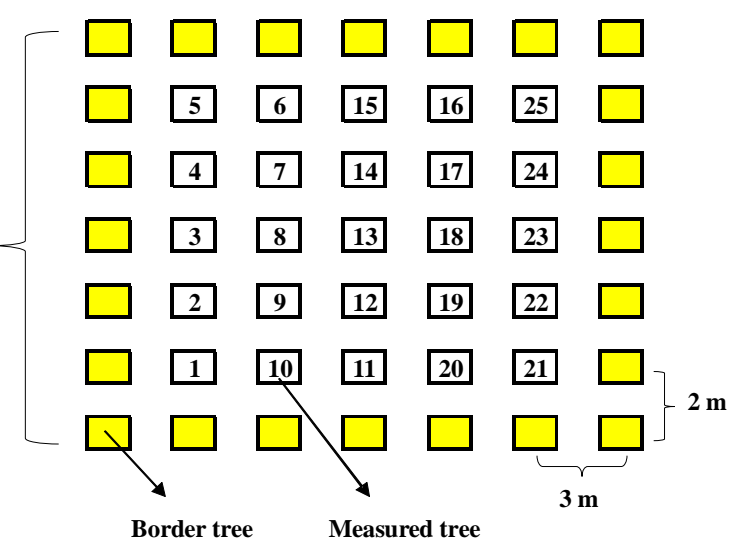

Figure 2 Layout of experimental design in the study site.

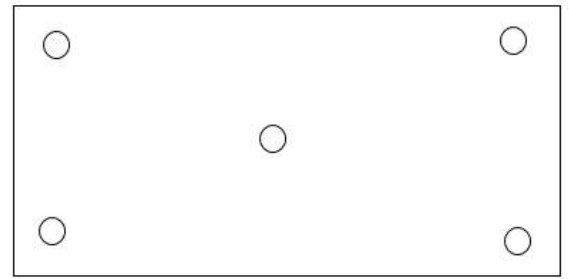

Figure 3 Five sample points for soil sampling in each block from the experimental site. 
Table 1 Soil properties in the site experiment based on the minimum (min), maximum (max), average (mean), and standard deviation (stdev) values of sand, sitl, clay, actual soil acidity, soil organic carbon, and cation exchange capacity

\begin{tabular}{|c|c|c|c|c|c|c|}
\hline \multirow{2}{*}{ Soil parameters } & \multirow{2}{*}{ Symbol } & \multirow{2}{*}{ Unit } & \multicolumn{4}{|c|}{ Results of laboratory analysis } \\
\hline & & & Min & $\operatorname{Max}$ & Mean & Stdev \\
\hline Sand fraction & SF & $\%$ & 30.00 & 36.00 & 32.00 & 2.65 \\
\hline Silt fraction & $\mathrm{SiF}$ & $\%$ & 25.00 & 28.00 & 26.14 & 1.21 \\
\hline Clay fraction & $\mathrm{CF}$ & $\%$ & 38.00 & 46.00 & 42.14 & 3.44 \\
\hline Soil acidity $\left(\mathrm{H}_{2} \mathrm{O}\right)$ & $\mathrm{pH}$ & - & 5.10 & 5.30 & 5.19 & 0.07 \\
\hline Soil organic carbon & SOC & $\%$ & 0.58 & 0.84 & 0.65 & 0.09 \\
\hline Cation exchange capacity & CEC & cmolc kg $^{-1}$ & 8.00 & 15.00 & 10.14 & 2.79 \\
\hline
\end{tabular}

The plant material of E. pellita used in this study was from provenance Muting, Merauke. Seed collection was obtained from a seedling seed orchad (SSO), owned by MHP. The seed was sown in the nursery around 3 months. A week before planting, the seedlings were graded for quality. In this study, only seedlings with a height of $30 \mathrm{~cm}$ and having healthy condition were utilized for field establishment. The seedlings were planted by initial spacing $3 \mathrm{~m} \times 2 \mathrm{~m}$ referring to the operations of this company (Figure 2). Intensive maintenance was also done to control weed competition by slashing and chemical spraying after planting in 3, 6, and 12 months.

Data collection and analysis In present paper, the observation was focused on the performance of E. pellita in the sixth months after field establishment. This period was commonly used by the majority of plantation forest company in Indonesia to conduct the first evaluation of experiment and ensure a quality control for operations, particularly in planting activity. Data collection was undertaken from October 2018 to December 2018. Four indicators were selected to evaluate the early growth of E. pellita, covering survival rate $(\%)$, height $(\mathrm{m})$, collar of diameter $(\mathrm{cm})$, and crown projection area $\left(\mathrm{m}^{2}\right)$. Survival rate was a ratio between actual density and initial density. Height was an average of trees height from aboveground to top crown estimated by measuring pole. Collar of diameter was a mean of trees diameter at $0.3 \mathrm{~m}$ aboveground measured by caliper. To calculate crown projection area (cpa), crown width (r) was measured in eight directions. Then, crown radius (cr) was understood as the quadratic mean of crown width (e.g. 1), and the transition between crown radius to crown projection area was expressed by the occupation area of tree (e.g. 2) (Pretzsch et al., 2015).

$$
\begin{aligned}
c r & =\sqrt{\frac{r_{N}^{2}+r_{N E}^{2}+\cdots+r_{N W}^{2}}{8}} \\
c p a & =\pi \times c r^{2}
\end{aligned}
$$

The destructive method was done to measure aboveground biomass and carbon storage. Every treatment was represented by five sample trees. After the selected trees were felled, we separated their components into stem, bark, branches, and leaves. The fresh weight of each component was recorded, and approximately $500 \mathrm{~g}$ sample was dried at $70{ }^{\circ} \mathrm{C}$ for $48 \mathrm{~h}$ in a forced-air oven for biomass determination. Then, carbon storage was estimated from total biomass in each component (Equation [3]) (Viera \& RodríguezSoalleiro, 2019).

\section{Carbon storage $=0.5 \times$ biomass}

The measurement of leaf characteristics was also implemented by destructive sampling. We sampled 30 leaves randomly from the total leaf harvested in every tree. The individual leaf area was measured by planimeter. Next, the sample leaves were also dried using a similar method like biomass determination. Specific leaf area (SLA) and leaf area index (LAI) were calculated for every sample tree (Equation [4] and Equation [5])(Hakamada et al., 2016).

$$
\begin{aligned}
\text { SLA } & =\frac{\text { Individual leaf area }}{\text { Individual leaf dry weight }} \\
\text { LAI } & =\frac{\text { total leaves biomass } \times \text { SLA }}{\text { cpa }}
\end{aligned}
$$

Statistical analysis was processed using software $\mathrm{R}$ version 3.6.1 with a significant level of 5\%. The descriptive test was used to identify the range of data distribution. The normality of data was examined with the KolmogorovSmirnov test. Homogeneity of variance among the treatments were evaluated by Levene's test. The influence of fertilization on early growth, aboveground biomass, carbon storage, and leaf characteristics in E. pellita was analyzed separately for each indicator using ANOVA and followed by HSD Tukey.

\section{Results and Discussion}

Early growth Results demonstrated that the treatment of fertilization did not have a significant effect on survival rate. Most of the treatments still had an average survival rate of more than $90 \%$. It indicated that the mortality of E. pellita caused by natural competition among trees is relatively low in the sixth months after field establishment. It was similar to a study reported by Woods \& Peseta (1996), who noted the mean mortality of $E$. pellita stand under one year still lower than $10 \%$. However, a meaningful influence of fertilization was observed in height, the collar of diameter, and the crown projection area. The increase of fertilization dose provided a positive trend to improve the early growth of E. pellita. At the treatment without fertilization, E. pellita presented lower growth performance than after the application of fertilizer. It signified that the actual soil properties were not able to supply adequate nutrients for E. pellita, particularly related 
to its phosphorus requirement. The highest mean height and collar of diameter were performed by P3, while P2 showed the greatest crown projection area. Nevertheless, this study did not record an extremely different growth of E. pellita between $\mathrm{P} 2$ and $\mathrm{P} 3$ statistically (Figure 4).

Compared to the treatment of control, fertilization using P2 and P3 for E. pellita considerably increased the early growth of E. pellita by approximately more than $50 \%$ for height, collar of diameter, and crown projection area. Both treatments also resulted better growth than the performance of E. pellita reported by Inail et al. (2015). In the similar period, P2 and P3 were could improve the average height of E. pellita by approximately $26.31 \%$ and $31.57 \%$. These results were also higher, around $9.09 \%$ and $13.63 \%$, than the growth of $A$. mangium that was developed in previous time (Inail et al., 2015).

This study observed that E. pellita exhibited a high response to increasing the dose of fertilization using triple superphosphate. This trend was also reported byHalomoan et al. (2015), who studied the response of eucalypts hybrids ( $E$. grandis $\mathrm{x}$ E. pellita) to different treatments of fertilization in Riau. Another study conducted by Amezquita et al. (2018) in Colombia also discovered more impressive growth of $E$. pellita in a higher concentration of phosphate fertilizer. It evidenced that $E$. pellita is a very required phosphorus nutrient to support its growth and development. However, the majority of soil type in the Indonesian plantation forest was ultisols that had primary problems related to low availability nutrients, particularly for phosphorus (Nurudin et al., 2013). Even though ultisols naturally had a high phosphorus content, but the availability of phosphorus for the plant was relatively low due to the fixation of phosphorus by aluminum and iron (Singh et al., 2015). For that reason, fertilization is very needed to support the management of $E$. pellita plantation in Indonesia. In this case, E. pellita would absorb the nutrient more effective when the fertilizer dissolved because it was placed inside of the planting hole near the root systems.

Aboveground biomass The total above-ground biomass of E. pellita was expressively affected by the treatment of fertilization. The similar results were also clearly documented on biomass distribution in stem, bark, branches, and leaves. P2 occupied the highest mean of above-ground biomass. This treatment extensively enhanced the average of aboveground biomass around four times higher than Control. In this early period, the majority of biomass in E. pellita from all treatments was distributed in leaves by approximately more than $50 \%$. These findings were commonly found in most eucalypts under one year because it was an important time to maximize crown development for obtaining optimum growing space and optimizing photosynthesis process (Table 2).

Interestingly, the biomass production of E. pellita showed by $\mathrm{P} 2$ was better than $\mathrm{P} 3$ even though for height and collar of diameter P3 exhibited better results. This outcome was possible because the crown projection area and LAI in P2 were higher than P3. Several studies documented both indicators had a strong correlation to biomass as they played important roles in photosynthesis (Smethurst et al., 2003;
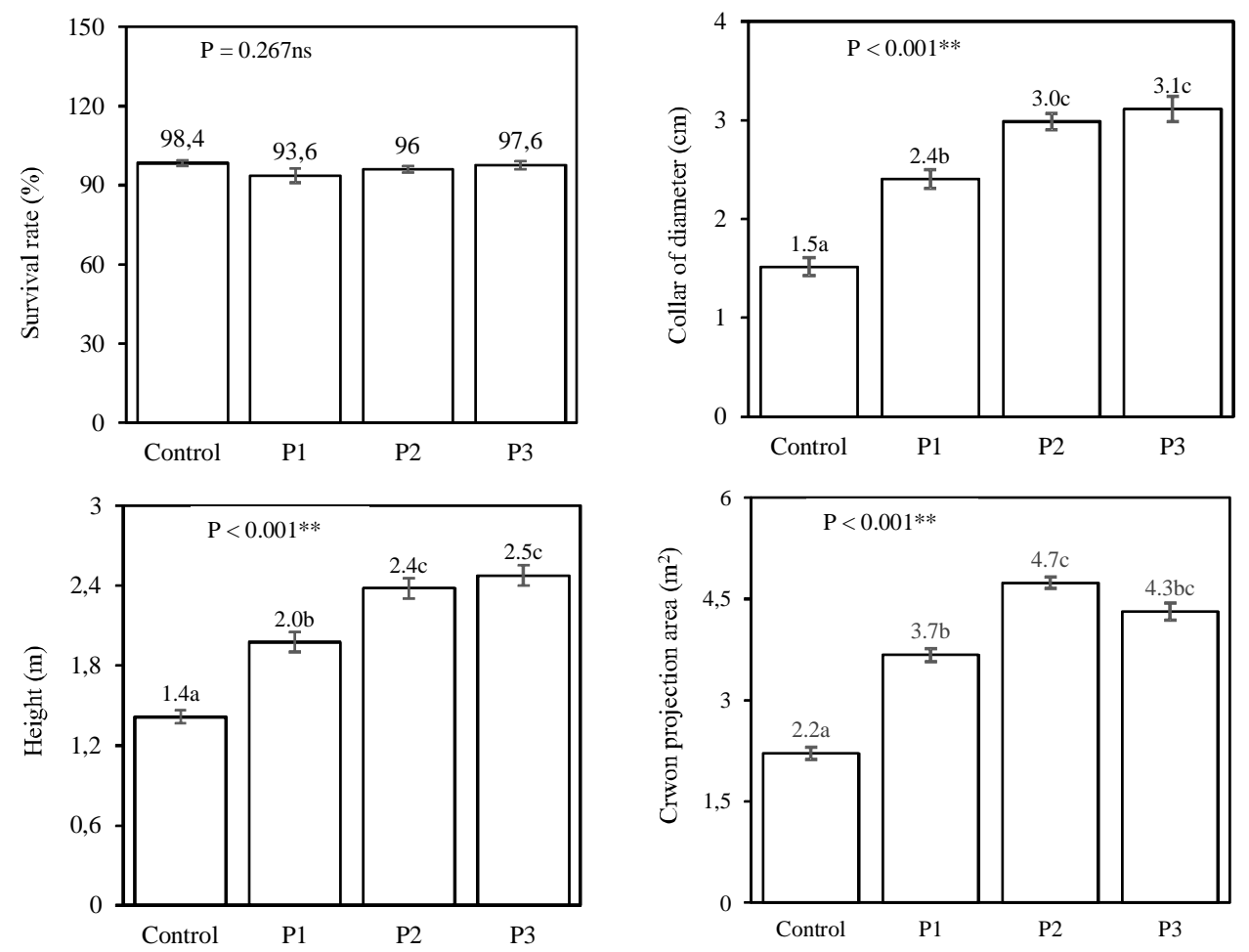

Figure 4 Survival rate, height, collar of diameter and crown projection area in E. pellita affected by fertilization. 
Tabel 2 Results of early growth, aboveground biomass, carbon storage, and leaf characteristics in E. pellita influenced by the treatment of fertilization

\begin{tabular}{|c|c|c|c|c|c|c|c|}
\hline \multirow{2}{*}{ Group of variables } & \multirow{2}{*}{ Measured parameters } & \multirow{2}{*}{ Units } & \multicolumn{4}{|c|}{ Treatment of fertilization } & \multirow{2}{*}{ p-value } \\
\hline & & & Control & P1 & $\mathrm{P} 2$ & P3 & \\
\hline \multirow[t]{4}{*}{ Early growth } & Survival & $\%$ & $98.40 \pm 2.19 \mathrm{a}$ & $93.60 \pm 6.06 \mathrm{a}$ & $96.00 \pm 2.82 \mathrm{a}$ & $97.60 \pm 3.58 \mathrm{a}$ & $0.267^{\mathrm{ns}}$ \\
\hline & Height & $\mathrm{m}$ & $1.41 \pm 0.11 \mathrm{a}$ & $1.98 \pm 0.17 b$ & $2.38 \pm 0.18 \mathrm{c}$ & $2.48 \pm 0.17 \mathrm{c}$ & $<0.001 * *$ \\
\hline & Collar of diameter & $\mathrm{cm}$ & $1.52 \pm 0.20 \mathrm{a}$ & $2.40 \pm 0.22 b$ & $2.99 \pm 0.19 \mathrm{c}$ & $3.11 \pm 0.29 c$ & $<0.001 * *$ \\
\hline & Crown projection area & $\mathrm{m}^{2}$ & $2.21 \pm 0.91 \mathrm{a}$ & $3.67 \pm 1.77 b$ & $4.74 \pm 0.88 \mathrm{c}$ & $4.31 \pm 1.00 \mathrm{c}$ & $<0.001 * *$ \\
\hline \multirow{5}{*}{$\begin{array}{l}\text { Aboveground } \\
\text { biomass }\end{array}$} & Stem biomass & $\mathrm{Mg} \mathrm{ha}^{-1}$ & $0.27 \pm 0.08 \mathrm{a}$ & $0.94 \pm 0.18 b$ & $1.83 \pm 0.63 \mathrm{c}$ & $1.20 \pm 0.49 \mathrm{bc}$ & $<0.001 * *$ \\
\hline & Bark biomass & $\mathrm{Mg} \mathrm{ha}^{-1}$ & $0.08 \pm 0.02 \mathrm{a}$ & $0.26 \pm 0.12 b$ & $0.56 \pm 0.17 b$ & $0.35 \pm 0.10 a b$ & $<0.001 * *$ \\
\hline & Branches biomass & $\mathrm{Mg} \mathrm{ha}^{-1}$ & $0.37 \pm 0.17 \mathrm{a}$ & $0.84 \pm 0.40 \mathrm{ab}$ & $1.51 \pm 0.41 \mathrm{c}$ & $1.18 \pm 0.45 b c$ & $<0.001 * *$ \\
\hline & Leaves biomass & $\mathrm{Mg} \mathrm{ha}^{-1}$ & $1.08 \pm 0.47 \mathrm{a}$ & $2.04 \pm 0.62 b$ & $3.40 \pm 0.65 \mathrm{c}$ & $2.85 \pm 0.30 \mathrm{bc}$ & $<0.001 * *$ \\
\hline & Biomass Accumulation & $\mathrm{Mg} \mathrm{ha}^{-1}$ & $1.80 \pm 0.73 \mathrm{a}$ & $4.08 \pm 1.14 \mathrm{~b}$ & $7.31 \pm 1.72 \mathrm{c}$ & $5.57 \pm 1.29 \mathrm{~b}$ & $<0.001 * *$ \\
\hline \multirow[t]{5}{*}{ Carbon storage } & Stem carbon & $\mathrm{Mg} \mathrm{ha}^{-1}$ & $0.14 \pm 0.04 \mathrm{a}$ & $0.47 \pm 0.09 b$ & $0.92 \pm 0.32 \mathrm{c}$ & $0.60 \pm 0.24 b c$ & $<0.001 * *$ \\
\hline & Bark carbon & $\mathrm{Mg} \mathrm{ha}^{-1}$ & $0.04 \pm 0.01 \mathrm{a}$ & $0.13 \pm 0.06 \mathrm{a}$ & $0.28 \pm 0.09 b$ & $0.17 \pm 0.05 \mathrm{ab}$ & $<0.001 * *$ \\
\hline & Branches carbon & $\mathrm{Mg} \mathrm{ha}^{-1}$ & $0.18 \pm 0.09 \mathrm{a}$ & $0.42 \pm 0.20 \mathrm{ab}$ & $0.76 \pm 0.20 \mathrm{c}$ & $0.59 \pm 0.23 \mathrm{bc}$ & $<0.001 * *$ \\
\hline & Leaves carbon & $\mathrm{Mg} \mathrm{ha}^{-1}$ & $0.54 \pm 0.23 \mathrm{a}$ & $1.02 \pm 0.31 \mathrm{~b}$ & $1.70 \pm 0.32 \mathrm{c}$ & $1.42 \pm 0.15 \mathrm{bc}$ & $<0.001 * *$ \\
\hline & Carbon accumulation & $\mathrm{Mg} \mathrm{ha}^{-1}$ & $0.90 \pm 0.37 \mathrm{a}$ & $2.04 \pm 0.57 \mathrm{ab}$ & $3.66 \pm 0.86 \mathrm{c}$ & $2.79 \pm 0.65 b c$ & $<0.001 * *$ \\
\hline \multirow[t]{4}{*}{ Leaf characteristics } & Individual leaf area & $\mathrm{cm}^{2}$ & $60.79 \pm 5.29 \mathrm{a}$ & $71.77 \pm 9.71 \mathrm{a}$ & $90.78 \pm 3.06 \mathrm{a}$ & $66.18 \pm 2.82 \mathrm{a}$ & $0.067^{\text {ns }}$ \\
\hline & Individual leaf dry weight & $\mathrm{g}$ & $7.20 \pm 0.06 \mathrm{a}$ & $11.10 \pm 0.08 b$ & $12.72 \pm 0.16 b$ & $7.76 \pm 0.02 \mathrm{a}$ & $0.026 *$ \\
\hline & Specific leaf area & $\mathrm{cm}^{2} \mathrm{~g}^{-1}$ & $8.45 \pm 0.31 \mathrm{a}$ & $6.47 \pm 0.92 \mathrm{a}$ & $8.57 \pm 0.24 \mathrm{a}$ & $8.61 \pm 0.22 \mathrm{a}$ & $0.078^{\mathrm{ns}}$ \\
\hline & Leaf area index & - & $2.49 \pm 0.54 \mathrm{a}$ & $2.49 \pm 0.72 \mathrm{a}$ & $3.85 \pm 0.36 \mathrm{~b}$ & $3.57 \pm 0.48 b$ & $0.043 *$ \\
\hline
\end{tabular}

* significant different at $\alpha 5 \%, * *$ significant different at $\alpha 1 \%,{ }^{\text {ns }}$ non significant different at $\alpha 5 \%$ based on ANOVA test. The number of same letter indicated non significant different according to HSD Tukey test at $5 \%$

Kitajima et al., 2005; Posada et al., 2009). The photosynthesis would become more optimum along with the rising of the crown projection area and LAI. Thus trees could generate higher biomass.

An expressive effect of fertilization on the growth of eucalypts species also have been investigated by other studies. Aguiar Ferreira and Stape (2009) found the biomass accumulation in E. urophylla improved around $14.49 \%$ in Brazil by high fertilization, especially from phosphate fertilizer. Zeng et al. (2013) observed that the application of fertilization had an opportunity to enhance the biomass production of eucalypts hybrid (E. grandis x E. urophylla) seedlings two times higher than no fertilization. Battie-laclau et al. (2016) reported the fertilization potentially increased stem biomass of E. grandis plantation more than $70 \%$ in Brazil.

The relationship between fertilization and biomass production in eucalypts species have been explored in many forestry studies. Higher biomass production would be obtained following the greater dose of fertilization due to the sufficient nutrient availability for eucalypts (Graciano et al., 2006; Silva et al., 2013; Albaugh et al., 2015). E. pellita was very required phosphorus because it was an essential macronutrient to compound plant structure and accelerate the biochemical reactions in the plant (Crous et al., 2019). A study informed that phosphorus had a vital role in capturing and converting solar energy into useful plant organs such as leaves, branches, bark, and stem (Yang et al., 2014). Nonetheless, there was a maximum limit of the nutrient requirement for every eucalypt. When the biomass production started declining along with the increasing of fertilization, it indicated the amount of nutrients was excessive and capable to contaminate eucalypts (Silva et al., 2013). Another study discovered the excess of phosphorus profoundly interfered with the absorbtion of other nutrients such as iron, manganese, and zinc(Novais et al., 2016).

Carbon storage Fertilization demonstrated a meaningful effect on carbon storage in each component of E. pellita. A high influence of fertilization was also clearly showed in total carbon storage. The highest carbon content of each component in E. pellita was surveyed in leaves, while the lowest was detected in the bark. The treatment of $\mathrm{P} 2$ provided the greatest mean of total carbon storage in E. pellita. It was approximately four times higher than the total carbon storage in control treatment (Table 2).

The concentration of carbon storage in E. pellita had a strong relationship with its biomass accumulation (Latifah \& Sulistiyono, 2013). Higher biomass production would result in greater carbon storage because carbon was the main material to compose biomass (Viera \& Rodríguez-Soalleiro, 2019). Carbon was an output from the photosynthesis process and accumulated in each component of plants (Johnson, 2016). This study presented where P2 generated the highest carbon storage as well as aboveground biomass.

Leaf characteristics Our observation reported that the different treatment of fertilization did not provide a 
significant influence on individual leaf area and specific leaf area. However, a substantial effect of fertilization was obviously showed by individual leaf dry weight and leaf area index. Compared to other treatments, P2 demonstrated the highest value for all indicators of leaf characteristics. The mean leaf area index in P2 was $35.32 \%$ higher than Control and $\mathrm{P} 1$, as well as $7.84 \%$ greater than $\mathrm{P} 3$ (Table 2).

Our results were different from what was discovered by Halomoan et al. (2015), where fertilization resulted in an extremely effect on individual leaf area and specific leaf area of eucalypts hybrid (E. grandis x E. pellita) in Riau. We assumed this distinction result was influenced by the different site conditions, the dose of fertilization, and kind of plant materials. This argument was also supported by a study documented by (Dwyer et al., 2019), who reported that the size of individual leaf area and dimension of specific leaf area was strongly influenced by the environmental gradient and growing space for plants.

A study stated that leaf characteristics, particularly the leaf area index, were an important indicator to assess the effectiveness of fertilization (Taugourdeau et al., 2014). It could also be used as a considering parameter to determine the optimum dose of fertilization for eucalypts (Smethurst et al., 2003). Leaf area index played an essential role in photosynthesis, light interception, water use, nutrient absorption, which was also a key determinant of tree growth and productivity (Jun et al., 2019). The highest leaf area index generally indicated the most suitable site condition for eucalypts (Toit \& Dovey, 2005). From this study, the highest leaf area index of E. pellita was recorded in the treatment of P2. It indicated this treatment might be an optimum dose of fertilization for E. pellita establishment in the study site. This initial presumptive was also evidenced by the greatest value of biomass production and carbon storage in the treatment of $\mathrm{P} 2$.

\section{Conclusion}

In the sixth months after field establishment, the different treatment of fertilization had a significant effect on height, collar of diameter, crown projection area, aboveground biomass, carbon storage, individual leaf dry weight, and leaf area index. However, this study did not observe a meaningful influence of fertilization on survival rate, individual leaf area, and specific leaf area. The highest mean height and collar of diameter were recorded in the treatment of $167 \mathrm{~kg} \mathrm{ha}^{-1}$ while the greatest aboveground biomass, carbon storage, and leaf characteristics were obviously seen in the dose of $133 \mathrm{~kg} \mathrm{ha}^{-1}$. Our study did not observe a highly different performance of E. pellita between both treatments statistically. Continuous monitoring was still required to guarantee the consistency performance of $E$. pellita in each treatment until the end of the rotation.

\section{Acknowledgment}

Authors are very grateful to PT Musi Hutan Persada that allows conducting this study as part of grand design for improving management of E. pellita and permits to publish this article. We also deliver our gratitude for his help to Dr. E. B. Hardiyanto for this help in the discussion and encouragement to write this article. Appreciation is also addressed to the Department of Research and Development in PT Musi Hutan Persada for supporting the implementation of this study. We also deliver our thankful to reviewers for their suggestions to this article.

\section{References}

Albaugh, T. J., Rubilar, R. A., Fox, T. R., Allen, H. L., Urrego, J. B., Zapata, M., \& Stape, J. L. (2015). Response of Eucalyptus grandis in Colombia to mid-rotation fertilization is dependent on site and rate but not frequency of application. Forest Ecology and Management, 350, 30-39. https://doi.org/10.1016/ j.foreco.2015.04.030

Amezquita, P. S. M., Rubiano, J. A. M., Filho, N. F. D. B., \& Cipriani, H. N. (2018). Fertilization effects on Eucalyptus pellita F. Muell productivity in the Colombian Orinoco Region. Revista Arvore, 42(5), 1-8. https://doi.org/ 10.1590/1806-9088201800050002

Bassaco, M. V. M., Motta, A. C. V., Pauletti, V., Prior, S. A., Nisgoski, S., \& Ferreira, C. F. (2018). Nitrogen, phosphorus, and potassium requirements for Eucalyptus urograndis plantations in southern Brazil. New Forests, 49(5), 681-697. https://doi.org/10.1007/s11056-0189658-0

Battie-Laclau, P., Delgado-Rojas, J. S., Christina, M., Nouvellon, Y., Bouillet, J., de Cassia Piccolo, M., ... Laclau, J. (2016). Potassium fertilization increases wateruse efficiency for stem biomass production without affecting intrinsic water-use efficiency in Eucalyptus grandis plantations. Forest Ecology and Management, 364,77-89. https://doi.org/10.1016/j.foreco.2016.01.004

Booth, T. H. (2013). Eucalypt plantations and climate change. Forest Ecology and Management, 301, 28-34. https://doi.org/10.1016/j.foreco.2012.04.004

Crous, K. Y., Ósvaldsson, A., \& Ellsworth, D. S. (2015). Is phosphorus limiting in a mature Eucalyptus woodland? Phosphorus fertilisation stimulates stem growth. Plant and Soil, 391(1-2), 293-305. https://doi.org/10.1007/ s11104-015-2426-4

Crous, Kristine Y., Wujeska-Klause, A., Jiang, M., Medlyn, B. E., \& Ellsworth, D. S. (2019). Nitrogen and phosphorus retranslocation of leaves and stemwood in a mature Eucalyptus forest exposed to 5 years of elevated $\mathrm{CO}_{2}$. Frontiers in Plant Science, 10(May), 1-13. https://doi.org/10.3389/fpls.2019.00664

da Silva, P. H. M., Poggiani, F., Libardi, P. L., \& Goncalves, A. N. (2013). Fertilizer management of eucalypt plantations on sandy soil in Brazil: Initial growth and nutrient cycling. Forest Ecology and Management, 301, 67-78. https://doi.org/10.1016/j.foreco.2012.10.033

da Silva, R. M. L., Hakamada, R. E., Bazani, J. H., Otto, M. S. G., \& Stape, J. L. (2016). Fertilization response, light use, and growth efficiency in eucalyptus plantations across 
soil and climate gradients in Brazil. Forests, 7(6), 2-13. https://doi.org/10.3390/f7060117

de Aguiar Ferreira, J. M., \& Stape, J. L. (2009). Productivity gains by fertilisation in Eucalyptus urophylla clonal plantations across gradients in site and stand conditions. Southern Forests, 71(4), 253-258. https://doi.org/10. 2989/SF.2009.71.4.1.1028

Dell, B., Hardy, G., \& Burgess, T. (2008). Health and nutrition of plantation eucalypts in Asia. Southern Forests, 70(2), 131-138. https://doi.org/10.2989/ SOUTH.FOR.2008.70.2.8.536

du Toit, B., \& Dovey, S. B. (2005). Effect of site management on leaf area, early biomass development, and stand growth efficiency of a Eucalyptus grandis plantation in South Africa. Canadian Journal of Forest Research, 35(4), 891-900. https://doi.org/10.1139/x04205

Dwyer, J. M., Hobbs, R. J., Mayfield, M. M., Dwyer, J. M., Hobbs, R. J., \& Mayfield, M. M. (2019). Specific leaf area responses to environmental gradients through space and time Ecology, 95(2), 399-410. https://doi.org/10.1890/13-0412.1

Estefan, G., Sommer, R., \& Ryan, J. (2013). Methods of soil, plant, and water analysis. Retrieved from https://www.gob.mx/siap/articulos/cierre-estadisticode-la-produccion-ganadera-2017?idiom=es

Fujita, M. S., Prawiradilaga, D. M., \& Yoshimura, T. (2014). Roles of fragmented and logged forests for bird communities in industrial Acacia mangium plantations in Indonesia. Ecological Research, 29(4), 741-755. https://doi.org/10.1007/s11284-014-1166-X

Gonçalves, J. L. M., Wichert, M. C. P., Gava, J. L., Masetto, A. V, Junior, A. J. C., Serrano, M. I. P., \& Mello, S. L. M. (2010). Soil fertility and growth of Eucalyptus grandis in Brazil under different residue management practices. Southern Forests : A Journal of Forest Science, 69(2), 95-102. https://doi.org/10.2989/SHFJ.2007.69.2.4.289

Graciano, C., Goya, J. F., Frangi, J. L., \& Guiamet, J. J. (2006). Fertilization with phosphorus increases soil nitrogen absorption in young plants of Eucalyptus grandis. Forest Ecology and Management, 236, 202-210. https://doi.org/10.1016/j.foreco.2006.09.005

Hakamada, R., Giunti Neto, C., de Lemos, C. C. Z., Silva, S. R., Otto, M. S. G., Hall, K. B., \& Stape, J. L. (2016). Validation of an efficient visual method for estimating leaf area index in clonal eucalyptus plantations. Southern Forests, 78(4), 275-281. https://doi.org/10.2989/ 20702620.2016.1201641

Halomoan, S. S. T., Wawan, \& Adiwirman. (2015). Effect of fertilization on the growth and biomass of Acacia mangium and Eucalyptus hybrid (E. grandis $\mathrm{x}$ E. pellita). Journal of Tropical Soils, 20(3), 157-166. https://doi.org/10.5400/jts.2015.20.3.157

Hardie, M., Mendham, D., Corkrey, R., Hardiyanto, E., Maydra, A., Siregar, S., ... Wibowo, A. (2018). Effects of eucalypt and acacia plantations on soil water in Sumatra New Forests, 49(1), 87104. https://doi.org/10. 1007/s11056-017-9607-3

Harwood, C. E., Alloysius, D., Pomroy, P., Robson, K. W., \& Haines, M. W. (1997). Early growth and survival of Eucalyptus pellita provenances in a range of tropical environments, compared with E. grandis, E. urophylla and Acacia mangium. New Forests, 14, 203-219. https://doi.org/10.1023/A:1006524405455

Harwood, C. E., \& Nambiar, E. K. S. (2014). Productivity of acacia and eucalypt plantations in South- east Asia . 2. trends and variations. International Forestry Review, 16(2), 249-260. https://doi.org/10.1505/14655481 4811724766 .

Hii, S. Y., Ha, K. S., Ngui, M. L., Ak Penguang, S., Duju, A., Teng, X. Y., \& Meder, R. (2017). Assessment of plantation-grown Eucalyptus pellita in Borneo, Malaysia for solid wood utilisation. Australian Forestry, 80(1), 26-33. https://doi.org/10.1080/00049158.2016.1272526

Inail, M. A., Thaher, E., \& Monica, S. (2015). Response of early growth Eucalyptus pellita to phosphorus fertilizer. Technical Notes, 1, 1-5.

Johnson, M. P. (2016). An overview of photosynthesis. Photosynthesis, 0, 255-273. https://doi.org/10.1042/ EBC20160016

Jun, D., Hong, L. E. I. X., \& Shi, L. R. J. (2019). Estimating single leaf area of Eucalyptus (Eucalyptus grandis $\mathrm{X}$ Eucalyptus urophylla) using leaf length and width. 2009 Third International Symposium on Plant Growth Modeling, Simulation, Visualization and Applications. https://doi.org/10.1109/PMA.2009.66

Kitajima, K., Mulkey, S. S., \& Wright, S. J. (2005). Variation in crown light utilization characteristics among tropical canopy trees. Annals of Botany, 95, 535-547. https://doi.org/10.1093/aob/mci051

Latifah, S., \& Sulistiyono, N. (2013). Carbon sequestration potential in aboveground biomass of hybrid eucalyptus plantation forest. Jurnal Manajemen Hutan Tropika, 19(1), 54-62. https://doi.org/10.7226/jtfm.19.1.54

Li, G., Zhang, Z., Shi, L., Zhou, Y., Yang, M., \& Cao, J. (2018). Effects of different grazing intensities on soil C, $\mathrm{N}$, and Pin an Alpine Meadow on the Qinghai - Tibetan. International Journal of Environmental Research and Public Health, 15, 1-16. https://doi.org/10.3390/ijerph 15112584

Lumbres, R. I. C., Lee, Y. J., Yun, C. W., Koo, C. D., Kim, S. B., Son, Y. M., .. Seo, Y. O. (2015). DBH-height modeling and validation for Acacia mangium and 
Eucalyptus pellita in Korintiga Hutani Plantation, Kalimantan, Indonesia. Forest Science and Technology, 11(3), 119-125. https://doi.org/10.1080/21580103. 2014.957356

Mcewan, A., Marchi, E., Spinelli, R., \& Brink, M. (2019). Past, present and future of industrial plantation forestry and implication on future timber harvesting technology. Journal of Forestry Research. https://doi.org/10.1007/ s11676-019-01019-3

Melo, E. A. S. C., Goncalves, J. L. M., Rocha, J. H. T., Hakamada, R. E., Bazani, J. H., Wenzel, A. V. A., ... Ferraz, A. V. (2016). Responses of clonal eucalypt plantations to $\mathrm{N}, \mathrm{P}$, and $\mathrm{K}$ fertilizer application in different edaphoclimatic conditions. Forests, 7(2), 1-15. https://doi.org/10.3390/f7010002

Mori, T., Ishizuka, S., Konda, R., Genroku, T., Nakamura, R., Kajino, H., ... Ohta, S. (2018). Potassium and magnesium in leaf and top soil affected by triple superphosphate fertilisation in an Acacia mangium plantation. Journal of Tropical Forest Science, 30(1), 1-8. https://doi.org/10.26525/jtfs2018.30.1.18

Nambiar Ao, E. K. S. (2015). Forestry for rural development, poverty reduction and climate change mitigation: We can help more with wood. Australian Forestry, 78(2), 55-64. https://doi.org/10.1080/00049158.2015.1050776

Nambiar, E. K. S., \& Harwood, C. E. (2014). Productivity of acacia and eucalypt plantations in Southeast Asia. 1. Biophysical determinants of production: opportunities and challenges. International Forestry Review, 16(2), 225-248. https://doi.org/10.1505/146554814811724757

Novais, S. V., Novais, R. F., Alvarez V., V. H., Villani, E. M. de A., \& Zenero, M. D. O. (2016). Phosphorus-zinc interaction and iron and manganese uptake in the growth and nutrition of phalaenopsis (Orchidaceae). Revista Brasileira de Ciencia Do Solo, 40, 1-10. https://doi.org/ 10.1590/18069657rbcs20160054

Nurudin, M., Ohta, S., Hardiyanto, E. B., Mendham, D., \& Wicaksono, A. (2013). Relationships between soil characteristics and productivity of Acacia mangium in South Sumatra. Tropics, 22(1), 1-12.

Payn, T., Carnus, J. M., Freer-Smith, P., Kimberley, M., Kollert, W., Liu, S., ... Wingfield, M. J. (2015). Changes in planted forests and future global implications. Forest Ecology and Management, 352, 57-67. https://doi.org/10.1016/j.foreco.2015.06.021

Pirralho, M., Flores, D., Sousa, V. B., Quilhó, T., Knapic, S., \& Pereira, H. (2014). Evaluation on paper making potential of nine Eucalyptus species based on wood anatomical features. Industrial Crops and Products, 54, 327-334. https://doi.org/10.1016/j.indcrop.2014.01.040

Posada, J. M., Lechowicz, M. J., Kitajima, K., \& Hall, B. (2009). Optimal photosynthetic use of light by tropical tree crowns achieved by adjustment of individual leaf angles and nitrogen content. Annals of Botany, 103, 795-805. https://doi.org/10.1093/aob/mcn265

Pretzsch, H., Biber, P., Uhl, E., Dahlhausen, J., Rötzer, T., Caldentey, J., ... Pauleit, S. (2015). Crown size and growing space requirement of common tree species in urban centres, parks, and forests. Urban Forestry and Urban Greening, 14(3), 466-479. https://doi.org/10. 1016/j.ufug.2015.04.006

Sasaki, N., Asner, G. P., Pan, Y., Knorr, W., Durst, P. B., Ma, H. O., ... Putz, F. E. (2016). Sustainable management of tropical forests can reduce carbon emissions and stabilize timber production. Frontiers in Environmental Science, 4,1-13. https://doi.org/10.3389/fenvs. 2016.00050

Shen, J., Yuan, L., Zhang, J., Li, H., Bai, Z., Chen, X., ... Zhang, F. (2011). Phosphorus dynamics: From soil to plant. Plant Physiology, 156(3), 997-1005. https://doi.org/10.1104/pp.111.175232

Simetti, R., Bonduelle, G. M., Silva, D. A. da, Mayer, S. L. S., Souza, H. P., \& Muniz, G. I. B. de. (2018). Production of biomass and energy stock for five Eucalyptus species. Revista Ciência Da Madeira-RCM, 9(1), 30-36. https://doi.org/10.12953/2177-6830/rcm.v9n1p30-36

Singh, G., Goyne, K. W., \& Kabrick, J. M. (2015). Determinants of total and available phosphorus in forested alfisols and ultisols of the Ozark Highlands, USA. Geoderma Regional, 5, 117-126. https://doi.org/ 10.1016/j.geodrs.2015.05.001

Smethurst, P., Baillie, C., Cherry, M., \& Holz, G. (2003). Fertilizer effects on LAI and growth of four Eucalyptus nitens plantations. Forest Ecology and Management, 176, 531-542. https://doi.org/10.1016/S03781127(02)00226-8

Taugourdeau, S., Avelino, J., Jones, J. R., Ramirez, L. G., Jara, M., Charbonnier, F., ... Roupsard, O. (2014). Leaf area index as an indicator of ecosystem services and management practices: An application for coffee agroforestry. "Agriculture, Ecosystems and Environment,” 192, 19-37. https://doi.org/10.1016/ j.agee.2014.03.042

Tng, D. Y. P., Janos, D. P., Jordan, G. J., Weber, E., \& Bowman, D. M. J. S. (2014). Phosphorus limits Eucalyptus grandis seedling growth in an unburnt rain forest soil. Frontiers in Plant Science, 5, 1-11. https://doi.org/10.3389/fpls.2014.00527

van Bich, N., Mendham, D., Evans, K. J., Dong, T. L., Hai, V. D., van Thanh, H., \& Mohammed, C. L. (2019). Effect of residue management and fertiliser application on the productivity of a Eucalyptus hybrid and Acacia mangium planted on sloping terrain in northern Vietnam. Southern Forests, 81(3), 201-212. https://doi.org/10.2989/ 20702620.2018.1555940 
Viera, M., Fernández, F. R., \& Rodríguez-Soalleiro, R. (2016). Nutritional prescriptions for eucalyptus plantations: Lessons learned from Spain. Forests, 7(4), 1-15. https://doi.org/10.3390/f7040084

Viera, M., \& Rodríguez-Soalleiro, R. (2019). A complete assessment of carbon stocks in above and belowground biomass components of a hybrid eucalyptus plantation in Southern Brazil. Forests, 10(7), 536. https://doi.org/10. 3390/f10070536

Woods, P. V, \& Peseta, O. (1996). Early growth of Eucalyptus pellita on a range of sites in Western Samoa.
Commonwealth Forestry Review, 75(4), 334-337. Retrieved from https://www.jstor.org/stable/42608909

Yang, X., Tang, Z., Ji, C., Liu, H., Ma, W., Mohhamot, A., ... Zheng, C. (2014). Scaling of nitrogen and phosphorus across plant organs in shrubland biomes across Northern China. Scientific Reports, 4, 1-7. https://doi.org/ 10.1038/srep05448

Zeng, S., Jacobs, D. F., Sloan, J. L., Xue, L., Li, Y., \& Chu, S. (2013). Split fertilizer application affects growth, biomass allocation, and fertilizer uptake efficiency of hybrid Eucalyptus. New Forests, 44(5), 703-718. https://doi.org/10.1007/s11056-013-9371-y 